\title{
Financial Innovations for SMEs in Sri Lanka
}

\author{
S. A. U. Niranjala \\ Department of Economics, Rajarata Univesity of Sri Lanka
}

\begin{abstract}
In Sri Lanka, SMEs play a significant role and are more constrained by different obstacles, and limited access to finance is a significant problem. The purpose of this paper was to investigate financial innovations to develop SMEs in Sri Lanka. The study was based on primary and secondary sources. Primary data were from SMEs' owners or managers gathered by using survey methods. The sample comprised 63 SMEs in Sri Lanka operating different kind of industries. The finding reveals that commercial banks' loans are the most critical source of SME financing, even though the SME has many difficulties in dealing with banks. Leasing financing and loans from other financial institutions are less important than other financial sources. Equity financing, venture capital, and factoring are uncommon among SMEs in Sri Lanka. Indeed, there was evidence that SMEs in Sri Lanka still preferred to use traditional financing sources instead of innovative financial sources. Furthermore, SMEs do not have sufficient knowledge about innovative financial authorities, and financial institutions fail to provide adequate support for SMEs. Promoting programs to develop managerial and IT skills for SMEs, establishing particular banks for SMEs related to the small community, and other financial such as factoring and venture capital can be developed to reduce SMEs' financing problem in Sri Lanka.
\end{abstract}

Keywords: Access to Finance, Financial Innovations, SMEs

DOI: $10.7176 / \mathrm{JESD} / 11-20-08$

Publication date:October $31^{\text {st }} 2020$

\section{Introduction}

Economic development is the ultimate purpose of every government in the world. Towards this end, SMEs play a significant role in economic development in any country. SMEs help to alleviate the contradiction between the gaps in the rich and the poor. The SMEs mainly contribute to the GDP, reduce unemployment problems, and alleviate poverty. On the other hand, SMEs serve as a nursery for large enterprises of the future, as most large enterprises originated as SMEs in the past. However, the evidence exemplified that SMEs' financial problem is one of the most significant constraints (Gamage, 2003; Wickrremasinghe, 2011; Gunatilake, 2018). Such financial issues delay SMEs competitiveness and further development. The SMEs need finance in every stage of their development from beginning to developing the ultimate level. Furthermore, less financial access, which enormously influences delays investment of SMEs. Consequently, Sri Lanka SMEs cannot expand and boost its competitiveness with limited access to financing from formal sources. It causes to loss of business and entrepreneurs and a significant loss for the Sri Lankan economy in general.

By recognizing the role of SMEs in the economy, governments in both developed and developing nations have established and or facilitate different funding programs and institutions to provide easy access for SMEs aiming to finance in each stage of their development (Rupeika - Apoga and Danovi, 2015; Prelipcean and Boscoianu, 2014). Various research reveals that many alternative formal sources of financing schemes for SMEs in many countries are available. These include venture capital, credit guarantee, import trade financing, export trading financing, trade credit, factoring, leasing, loan term from banks, securitization of loan, and capital markets (Abdulsalesh and Worthington, 2013). Moreover, developing countries can access special aid and loan assistance schemes from international financial institutions such as the Asian Development Bank (ADB), International Financial Corporation (IFC), and various other international donor institutions. Nevertheless, such kinds of international assistance are underprivileged in Sri Lanka due to many constraints and, most of the alternative sources of financing are also poorly exist. So, SMEs' financial innovations are one of the best solutions for SMEs' inadequate formal financial sources. The financial design for SMEs has become a subject of academic interest in recent years. Because financial innovations for SMEs have become the major sector SMEs' development in both developed and developing countries.

Financial innovation is defined as creating or designing new financial products, better processes, efficient systems, and institution alliances. It also entails the constant improvement of financial institutions' existing products and activities to meet the stakeholders' emerging needs (Tufano, 2003). Therefore, SMEs' financial innovation can be identified as a new development in any component of the SMEs' financial system. It may include financial markets, financial institutions, financial instruments, and financial regulations. Any improvement related to SMEs of the above sectors may be directly affected by the development of SMEs.

Although Sri Lankan government has identified the necessity of financial innovation for SMEs and proposed some programs to solve SMEs' financial requirements, financing is still a significant problem among SMEs (Gamage, 2003; Wickrremasinghe 2011). Further, only hand-full papers study the SMEs and lacuna in published 
articles that examine innovative financial programs. Therefore, this research mainly focuses on identifying the innovative financial programs, instruments, factors that affect financial access, models for SMEs, and comparing the innovative financial tool and methods with other countries.

\section{Literature summary}

\subsection{Financial innovation - definition}

Financial innovation defines as the act of creating and then popularizing new financial instruments, technologies, institutions, markets, processes, and business models - including the latest application of existing ideas in a different market context (Tufano, 2003). Frame \& White (2004) financial innovation is defined as product and organizational design, which allow cost or risk reduction for a single bank/or improve the financial system's services as a whole. Financial innovation is the design of new financial instruments and financial intermediation techniques, structural change in the financial system, changes in organization and behavior of institutions, and new financial instruments of packaging and existing financial instruments. Financial innovations can be grouped as new products (e.g., adjustable-rate mortgages; exchange-traded index funds); new services (e.g., online securities trading; Internet banking); original "production" processes (e.g., electronic record-keeping for securities; credit scoring); or new organizational forms (e.g., a new type of electronic exchange for trading securities; Internet-only banks).

According to them, banks play a significant part in financial innovation. But, banks are not the only developer of financial innovation. The banking sector is also an end-user of innovations developed in other sectors. Sometimes banks jointly developed innovations with non-financial institutes. In a country, the financial sector comprises of different institutes. So any development or creation related to the financial sector can be considered as financial innovations. Every financial innovation is not related to SMEs. Some financial innovations are directly focused on SMEs, but some financial innovations are indirectly effected by SMEs. Indeed, the term of financial innovations for SMEs can be applied in two meanings. According to a narrow definition, SMEs' financial innovations are defined as any new development in financial instruments (entirely new tools, the combination of traditional instruments, modification of traditional instruments, a new application of existing instruments, etc.). According to a broad definition, SMEs' financial innovations include any new developments in any financial system (markets, institutions, mechanisms, and regulations) (Ionescu, 2012).

\subsection{SMEs and access to finance}

SMEs are facing numerous difficulties worldwide. Empirical studies have highlighted that access to finance represents one of the most significant challenges for SMEs' entrepreneurs (Beck et al., 2008; Rupeika-Apoga, 2014; Boscoianu et al., 2015; Hunjra, 2011). Helmut and Frank Lang stated that even at a time of economic boom, the smallest enterprises often experience securing financing. According to Kraemer-eis and Lang, small companies' financing has more difficulties than the financing of large companies (Kraemer-eis and Lang, 2012). SMEs receive limited external funding compared to large firms and face a financing gap - even if they deliver employment to a large share of the workforce in developing countries (Megersa, 2020). Numerous studies that use firm-level survey data demonstrate access to finance as barriers to SME financing (Schiffer and Weder, 2001; Galindo et al., 2002; Beck and Demirguc-Kunt, 2006). SMEs find it more difficult than larger firms to obtain external finance for several reasons (Beck et al. 2006; Beck et al. 2008; Kraemer-eis, 2014). Therefore, Beck concluded that smaller firms in countries have underdeveloped financial and legal systems to use external finance (Beck et al., 2008).

Financial support is essential for SME's development (Salikin et al., 2014).

But, there are not enough funding programs schemes to assist SMEs; most SMEs are not aware of funding programs and financial schemes provided by the government and private sector. Further, the Public and private sectors have not put enough funding programs and financial systems to assist SMEs (Osano and Languitone, 2016). Financial aid refers to financial assistance from various institutions and organizations to start a new business or improve the existing SMEs' business (Rakicevic et al., 2016). Pretorius and Shaw (2004) identified two important financing concepts of SMEs: the internal and external financing. Internal financing is the leading choice, an important source to get finance (Alina, 2011). SMEs mostly depend on internal financings, like personal savings and business profits, due to low formal external financing sources. External resources are essential providers for SMEs' growth (Beck and Demirguc-Kunt, 2006; Mazzucato, 2013; Lee et al., 2015). According to Tchankam, young small businesses come from internal sources and personal and informal investors. These businesses grow; they need additional capital and must turn to external authorities (Tchankam et al., 2016).

On the other hand, the source of funds for SMEs are categorized as informal and formal sources. Financing from family and friends keep on as an informal source of finance for SME operators (Alina, 2011; Kraemer-eis and Lang, 2012). Gbandi and Amissah (2014) stated that the informal sector consists of informal financing institutions like money lenders, landlords, friends, relations, credit, and savings. Indeed, SMEs are significantly financed by informal sources of finance than the formal basis of finance. More profitable SMEs used to use external sources of financing, like financial banks, individual investors, venture capital, crowdfunding, and then make out 
successful firms (Beck and Demirguc-Kunt, 2006; Mazzucato, 2013; Lee et al., 2015).

\subsection{Major formal sources of SMEs financing}

2.3.1 Financing from commercial banks

An extensive prevailing literature has recognized that banks are the leading external finance provider for SMEs in developed and developing countries (Prohorovs and Beizitere, 2015; Cusmano, 2015; Kraemer- eis and Lang, 2012). Moro advised that SMEs should only focus on bank financing (Moro, 2010). But, when applying for a loan from banks, SMEs faced some obstacles like, better prepared for a loan (Haron et al., 2013), enough guarantee (Chao and Zongfang, 2013), historical records (Zeneli and Zaho, 2014), and political connections (Song et al., 2015).

Kraemer-Eis and Lang emphasized that countries with a highly developed capital market and financial services for enterprises have more significant opportunities to substitute bank loans with alternative financing (Kraemer-Eis and Lang, 2012). The empirical literature on bank financing to SMEs emphasized that most banks in a country do not pay sufficient attention to SMEs' development because of their risky nature. SMEs have less opportunity to access finance through a bank (Abdesamed and Wahab, 2012). Less collateral is the main problem in SMEs. SMEs without collaterals are challenging to obtain debt finance form commercial banks. Therefore it is necessary to have either business or personal assets used as collaterals when applying for the credit (Fatoki and Asah, 2011; Thanh et al., 2011; Lin, 2012).

\subsubsection{Financing SMEs through trade credit}

In addition to bank lending, there are other kinds of external sources available to finance SMEs globally. Abdulsalesh (2013) stated that those financing sources are equity financing, venture capital, business angels, trade credit, and non-bank financial institution debt. Trade credit can be considered as one of the most important sources of external financing for SMEs. (Berger and Udell, 2006). SMEs do not require to be paid immediately by receiving the goods by suppliers. Instead, suppliers offer credit terms that allow the buyers to delay the payment. This practice is called trade credit. Trade credit dealings typically involve short-term (e.g., thirty to sixty days) delayed purchases of intermediate goods or services. Through delayed payment, trade credit suppliers are effectively funding their clients with short-term debt. Although trade credit is a more critical short-term financing source for smaller firms, it is more expensive if payments are not made within the stipulated conduct window (Wilson and summer, 2002). Supplementary, trade credit can be used as alternative financing sources when other alternative financing sources are unavailable or more expensive. Besides, (Olawale and Garwe, 2010; Berger and Udell, 2006) argued that trade credit financing is favored by new and young SMEs when the risk of default is high. However, Berger and Udell (2006) believe that trade credit remains a critical financing source for most SMEs, mostly the young, despite some disadvantages.

\subsubsection{Financing SMEs through leasing}

Leasing can be considered an alternative financial instrument to facilitate SMEs' access to finance (Hossain, 2013). Leasing, in general, is regarded as a method of funding the procurement of capital equipment. Machinery, equipment, vehicles, and property of many businesses can be obtained through leasing. Ownership of the assets does not transfer to the borrower until financed and fully discharged the lease obligation. So, leasing's key advantage is that they can fulfill their assets needs rather than investing direct capital.Further lower down payment, credit availability, simple documentation and security arrangements, faster credit approval, and tax incentives are also advantages of leasing other alternative financial instruments. On the other hand, SMEs with less collateral and cash-flow can be attracted by the leasing (Hossain, 2013). Kraemer-Eis also stated that financing is an essential tool for SMEs which provide funding close to the investment period of the least assets like collaterals (KraemerEis and Lang, 2012). Although there were advantages of leasing, Kraemer (2012) highlighted that SMEs considered leasing are expensive financial tools for SMEs entrepreneurs.

\subsubsection{Financing SMEs through venture capitalists}

Venture capitalists are also considered an alternative source for financing SMEs and financial intermediaries (Abdulsaleh and Worthington, 2013). The venture capital market includes various organizations, including public corporations, small business investment corporations, and private limited partnerships. Venture capitalists raise and manage funds, a pool of money raised by both public and private investors. Venture capitalists identify entrepreneurs with promising new ideas and assist with funding and professional management. Venture Capital is one source of non-bank financing, which is quite prevalent in developed financial markets for small or start-up firms.

In developing countries, venture capital funds have become a critical financing source for SMEs, which often have difficulty raising long-term financing because of underdeveloped capital markets. In developing countries, there are challenges for venture capital funds because of the weak institutions and legal and regulatory frameworks 
having less supported the implementation of contracts with the enterprises they invest(Abereijo and Fayomi, 2007). Indonesia has identified venture capital companies as the alternative sources of funding for SMEs and star-ups. Their business activities include equity participation, participation through purchasing convertible bonds, and profit share financing. The venture capital industries have been growing in Indonesia, although it is relatively small in scale (OECD, 2015). In Spain, according to the Spanish Association of Venture Capital (ASCRI), venture capital and private equity companies remain mostly focused on SMEs, having financed 543 companies in 2012, out of which $90 \%$ were transactions of less than EUR 5 million to start-ups and early-phase expansion companies. Fiscal incentives are used to promote Spain's venture capital investment, such as only having to pay a $1 \%$ corporate income tax $(\mathrm{OECD}, 2015)$

\subsubsection{Financing SMEs through non-bank financial institutions}

Non-financial institutions can be considered as an important sector for financing SMEs (Tsai, 2015). Those are credit unions, pension funds, finance houses, investment trust companies, finance companies, and insurance companies (Arena, 2011). Existing literature shows that the market for the non-bank debt has been ignored by many SMEs to succeed in their financial needs (Arena, 2011). But, in both developed and developing countries, non-bank debt can be considered as significant financial sources for SMEs to increase their financial requirements (Aryeetey, 1998; Ahemed and Chowdhury, 2007). In a study conducted by Ahmed (2007) in Bangladesh, NBFIs are considered a vital financial system element. An efficient NBFIs sector can contribute to the economy's financial stability.

\subsection{SMEs supportive program from world experience}

\subsubsection{Establishment of separate institute or market for SMEs}

The establishment of an independent institute or market for SMEs was the one solution for SMEs' financial innovations. As an example, the implementation of a "secondary Stock Exchange Market" for SMEs was one solution for access to finance in SMEs (Rupeika-Apoga and Danovi, 2015). There should be a national level implementation program through financial instruments such as microloans, start-up loans, growth loans, colending, and loan guarantees. Indeed, establishing national-level one-stop financial intermediaries will guide and support SMEs through the entire process of attracting finance with minimal administrative problems. The development of specialized SME financial institutions was another solution to facilitate SME financial requirements (Kyaw, 2008). Quoye \& Sarbah (2014) also revealed that a lack of information about alternative sources' existence would cause financing problems. It is necessary to establish a unit to provide essential information to SMEs. In Thailand, there was a separate bank for SMEs named as SME bank. The SME bank's primary objectives were developing, promoting, and assisting SMEs to a start-up business, export or import their business by providing loans, guarantees, venture capital, counseling, and other necessary services (Punyasavatsut, 2011).

\subsubsection{Crowdfunding}

Crowdfunding is an acceptable substitute method of raising finance for people with creative projects to fund their goals. It involves asking and collecting relatively small amounts of money from a large number of people. Belleflamme, Lambert, and Schwienbacher (2011) crowdfunding is defined as collecting money for investments through social networks on the Internet. Eniola and Entebang (2015) considered crowdfunding as an alternative source for SME financing. But to effectively function in a country, the government needs to provide the regulatory environment that will support crowdfunding. Further, crowdfunding offers financing for commercial ventures through multiple small-scale investors (Pierrakis and Collins, 2013). Widuto (2014) also agreed as crowdfunding as an alternative financing opportunity for SMEs. But it involves specific risk, namely risk of fraud, platform closure or failure, project default, cyber-attack, donor exhaustion, misleading advertising practices, legal uncertainty stemming from different legislation, liquidity risk (lack of exit options), and infringement of intellectual property rights.

\subsubsection{Build national credit rating agencies for SMEs}

The government can do financial innovations through improving debt financing for SMEs. Zeneli \& Zaho (2014) explained that the information asymmetry between banks and enterprises is the main reason for the SME's gaining funds so hard. Usually, the banks are not aware of the operating conditions credit situation of SMEs. So, the bank should redesign their credit - rating system. That will help to get more information about the reliability of their SME clients. Further, it is necessary to build national Credit Rating Agencies. Rational banks can cooperate with those agencies to reduce their information costs for SMEs. Indeed, they have mentioned that a national mechanism of sharing information should be built; banks can identify the SME's credit more effectively by taking advantage of these systems. From a long-term perspective, it helps to establish a cooperative relationship between banks and SMEs. This relationship will help SMEs and banks reduce financing costs, increase credit profits, evaluate credit 
risks, and enhance SMEs' competitiveness. With the development of technology, peoples are preferred to use more straightforward methods for their transactions. Shen et al., 2009 China has revealed another way to solve the problem is finance difficulties in SMEs by providing soft information critical for the SMEs' success. Further, the government and the banks should mutually agree on a credit guarantee scheme that will incorporate a risk-sharing arrangement to encourage banks to channel funds to SMEs (Terungwa, 2011).

\subsubsection{Improve the credit scoring system for SMEs}

In Indonesia's case (Huda, 2012), lending to SMEs by banks prevents asymmetric information. They proposed that the government should involve solving this problem by providing data on the widely dispersed SMEs. If there were adequate data, the bank can easily find them and support SMEs. Also, the feasibility of the business must be evaluated. Improving the credit scoring system permitted the government to assess SMEs' viability and the banks' ability to consider businesses' risks. The government should have a database of SMEs in its region. It will allow the government to act as a strategic partner for the banks in its financing distribution to SMEs.

\subsubsection{Hybrid solution VCF/PEF-PPP}

Boscoianu et al. (2015) has researched a hybrid solution for SME financing in Romania and introduced an innovative type of Hybrid solution for SMEs named as VCF/PEF-PPP. It is a creative mix of private management and government support. It is not new tools, but it is based on an innovative mix of private management and governmental support of a new type of financial public-private partnership (PPP). Prelipcean and Boscoianu (2014) pointed out that, even in the emerging European countries, access to conventional financial sources are limited. Therefore, the government should answer more actively to solve SMEs' growing difficulties in accessing finance. The government can solve these problems through various programs such as loan guaranteed programs, direct lending programs, micro-credit loans, and other guarantees. Further, the government should consider attractive, innovative schemes such as public-private partnerships (PPP) and special keen investment funds with a flexible structure.

\subsubsection{Another Development program}

The story of micro-financing was an effective solution for access to finance in SMEs. Ibrahim (2012) has employed research about Indonesians' financing problems and proposed another way for financial innovation to be microfinancing. Some institutions in Indonesia have already engaged in micro-financing. None of them has maximized the use of internet technology to promote and mobilize the mass. Promoting the internet technology microfinancing program can be done smoothly and effectively.

Different countries used various financial innovations to develop SMEs even if the problem was the same for every country. For example, In Thailand, several financial designs have been done to create SMEs' access to finance. In 2000, the first SME promotion Act was promulgated. The SME promotion office was set up in the same year as a coordination body for SME development among government agencies. SME promotion policy had three central plants, investment promotion, financial assistance, and technical and management consultancy. Further, the Thai government has established several initiatives in financing. They are; setting up the SME bank in 2002, setting up the Small Business Credit Guarantee Corporation (SBCG), setting up the Venture Capital Fund under the office of SME promotion to assist SMEs, establishing the Market for Alternative Investment (MAI) to increase access to capital via equity financing, establishment of Center for Credit Access problem Alleviation (Punyasavatsut, 2011).

On the other hand, India has three different types of financial arrangements for financing innovations. They are research grants, tax incentives, and venture capital. Grants and loans are available through many finance schemes such as the Technology Development Board, Techno-entrepreneurs Promotion Program, and the New Millennium India Technology Leadership Initiative. Substantial funds are available from these sources for innovations to transfer from the design stage to the commercial location (Nanayakkara, 2011). Further, Vietnam has supported SME development for many years via improving legal frameworks, entrepreneurship education and training, simplifying staring a business, providing service for skills development, improving online access to government agencies and information, expanding technological capacity, assisting in the operation of e-business (Thanh et al., 2011).

\subsection{Sri Lankan situation about SMEs}

\subsubsection{Small and Medium Enterprises (SMEs) - Definition}

At present, Sri Lanka does not have a nationally accepted definition for SMEs. Different agencies have variously defined SMEs in terms of either value of fixed assets, the size of employment, or a combination of both (Table 01). 
Table 01- Definition for SMEs in Sri Lanka

\begin{tabular}{|l|l|l|l|l|}
\hline Sectors & Criteria & Medium & Small & Micro \\
\hline \multirow{2}{*}{$\begin{array}{l}\text { Manufacturing } \\
\text { Sector }\end{array}$} & Annual Turnover & Rs. Mn. 251-750 & Rs. Mn. 16-250 & Less than Rs. Mn. 15 \\
\cline { 2 - 5 } Service Sector & No. of Employees & $51-300$ & $11-50$ & Less than 10 \\
\cline { 2 - 5 } & Annual Turnover & Rs. Mn. 251-750 & Rs. Mn. 16-250 & Less than Rs. Mn. 15 \\
\cline { 2 - 5 } & No. of Employees & $51-200$ & $11-50$ & Less than 10 \\
\hline
\end{tabular}

(Source: National Policy Framework for SME Development, Ministry of Industry and Commerce)

The Economic Census conducted in 2013/14 also defined SMEs as follows.

Table 2 - Definition of SMEs in Sri Lanka

\begin{tabular}{|l|l|l|}
\hline Economic Sector & Levels & $\begin{array}{l}\text { Criteria } \\
\text { (Number of Persons Engaged) }\end{array}$ \\
\hline Industry and Construction & Micro & $1-4$ \\
& Small & $5-24$ \\
& Medium & $25-199$ \\
& Large & 200 and above \\
\hline Trade & Micro & $1-3$ \\
& Small & $4-14$ \\
& Medium & $15-34$ \\
& Large & 35 and above \\
\hline Services & Micro & $1-4$ \\
& Small & $5-15$ \\
& Medium & $16-74$ \\
& Large & 75 and above \\
\hline
\end{tabular}

(Source: Department of Census and Statistics, 2015)

\subsubsection{SMEs in Sri Lanka}

Micro-businesses are the most popular sector in Sri Lanka, contributing over $90 \%$ in the number of establishments. SMEs contribute only $8 \%$ in terms of the number of establishments. The majority of micro establishments are in rural areas, and the large and medium-scale establishments in the country are mostly condensed in urban areas, according to table $03.75 .3 \%$ of micro establishments have been distributed in rural areas, whereas around $50 \%$ of medium and $61 \%$ of large scale establishments were implemented in urban areas.

Table 03- Distribution of SMEs by Sector

\begin{tabular}{|l|l|l|l|l|l|l|l|l|}
\hline \multirow{2}{*}{ Sector } & Total & Urban & Rural & \multicolumn{2}{l|}{ Estate } \\
\cline { 2 - 10 } & Number & $\%$ & Amount & $\%$ & Amount & $\%$ & Amount & $\%$ \\
\hline Micro & 935736 & 91.7 & 216204 & 23.1 & 705074 & 75.3 & 14458 & 1.6 \\
\hline Small & 71126 & 07.0 & 27999 & 39.4 & 42683 & 60 & 444 & 0.6 \\
\hline Medium & 10405 & 01.0 & 5164 & 49.6 & 4989 & 47.9 & 252 & 2.5 \\
\hline Large & 2414 & 0.3 & 1461 & 60.5 & 909 & 37.7 & 44 & 1.8 \\
\hline Total & 1019681 & 100 & 250828 & 24.6 & 753655 & 73.9 & 15198 & 1.5 \\
\hline
\end{tabular}

(Source: Department of Census and Statistics, 2015)

Persons engaged in economic activities are the most important variable used by the statistical and other agencies worldwide as a proxy to define SMEs and measure the performance of an economy. As stated in table $3.5,91.7 \%$ of establishments in the country are micro-enterprises, whereas $7 \%$ are considered small, $1 \%$ is indicated as medium industries, and the balance and the $0.2 \%$ are recognized as large enterprises. Nevertheless, the number of persons engaged in those sectors shows an entirely different distribution. $44.5 \%$ of persons are engaged in micro-enterprises, $17.6 \%$ from small enterprises, $12.9 \%$ from the medium, and $24.9 \%$ are from large enterprises (Table 04).

Table 04 - Distribution of persons engaged and establishments

\begin{tabular}{|l|l|l|l|l|}
\hline \multirow{2}{*}{ Type of Industry } & \multicolumn{3}{|l|}{ No. of Establishments } & \multicolumn{2}{l|}{ Persons Engaged } \\
\cline { 2 - 5 } & Number & $\%$ & Number & $\%$ \\
\hline Total & 1019681 & 100 & 3003119 & 100 \\
\hline Micro & 935736 & 91.8 & 1338675 & 44.6 \\
\hline Small & 71126 & 7 & 529751 & 17.6 \\
\hline Medium & 10405 & 1 & 386756 & 12.6 \\
\hline Large & 2414 & 0.2 & 747937 & 24.9 \\
\hline
\end{tabular}

(Source: Department of Census and Statistics, 2015)

Considering the micro sector, $92 \%$ of SMEs' establishments are visible, but the generate employments are indicated only as $45 \%$ according to the calculation. However, only $0.2 \%$ has been represented as large establishments, and around $25 \%$ provide employments through these SMEs implementations. Accordingly, SMEs, 
which means $8 \%$ of the establishments, have created a job for about $31 \%$ of employees. These statistics proved the importance of SMEs for Sri Lanka as a non-industrial country. According to data represented in this figure, SMEs' establishments were less, and the person engaged in SMEs was satisfactory. It is exemplified that the development of SMEs is resources for the development of employment.

Gender of SMEs

SMEs' decision-makers are a significant variable in the SME sector in Sri Lanka as a developing country. Table 05 shows the behavior of gender in SMEs.

Table 05- Distribution of SMEs by Gender of Decision Makers

\begin{tabular}{|l|l|l|l|l|l|}
\hline Type of $\begin{array}{l}\text { Tymber of } \\
\text { industry }\end{array}$ & \multirow{2}{*}{$\begin{array}{l}\text { Numbecision Maker } \\
\text { Establishments }\end{array}$} & & Male & Female \\
\cline { 3 - 6 } & & Number & $\%$ & Number & $\%$ \\
\hline Total & 1019681 & 766766 & 75.2 & 252915 & 24.8 \\
\hline Micro & 935736 & 689471 & 73.7 & 246265 & 26.3 \\
\hline Small & 71126 & 65219 & 91.7 & 5907 & 8.3 \\
\hline Medium & 10405 & 9774 & 93.9 & 631 & 6.1 \\
\hline Large & 2414 & 2302 & 95.4 & 112 & 4.6 \\
\hline
\end{tabular}

(Source: Department of Census and Statistics, 2015)

The majority of industries are owned and or managed by male entrepreneurs, which indicates around 75 percent. The female contribution is high (26.3 percent) in micro industries compared with other industries' levels. Table 05 shows that the less female contribution for SMEs in Sri Lanka. It was indicated in small sectors at 8.3 percent, while in the medium sectors, 6.1. To sum up, it is assumed that female contributions can reduce female un-employability within the industrial sector in Sri Lanka when industries developed.

\section{Methodology and Discussion}

North Central Province in Sri Lanka was selected as the research site. The study was guided by self-administered questionnaires and interviews with semi-structured questionnaires. It was hypothesized that the owners and managers in SMEs would have an improved positive perception of SME's financial innovations. A total of 63 respondents, including males (54); and females (09), participated in this survey. Respondents voluntarily consented to participate in the completion of this questionnaire and open-ended survey items.

\subsection{Profile of the SMEs owners/managers}

The total sample consisted of 63 respondents and owner/manager characteristics shown in table 06 . The majority of SMEs were male $(85.7 \%)$ with primary education $(74.6 \%)$ and, most of the SMEs were in age between 35-44 years, which recorded as 44.4 percent.

Table 06- Profile of the SMEs owner/manager

\begin{tabular}{ll}
\hline Demography of Respondents & Frequency (\%) \\
\hline & $\mathrm{n}=63$ \\
Age (Yrs) & \\
$25-34$ & $04(6.3)$ \\
$35-44$ & $06(9.5)$ \\
$45-54$ & $28(44.4)$ \\
$>55$ & $18(28.6)$ \\
Gender & $07(11.2)$ \\
Male & \\
Female & $54(85.7)$ \\
Educational Level & $09(14.3)$ \\
$<$ G.C.E (O/L) & \\
G.C.E (O/L) & $06(9.5)$ \\
G.C.E (A/L) & $47(74.6)$ \\
Graduate & $10(15.9)$ \\
Postgraduate & $0(0.0)$ \\
\hline
\end{tabular}

(Source: Survey data 2019)

\subsection{The Profile of the SMEs Firm}

Table 07 presents the characteristics of SMEs based on various factors such as experience, age of business and number of employees. 
Table 07 Profiles of the SMEs Firms in Sri Lanka

\begin{tabular}{ll}
\hline Characteristics & Frequency (\%) \\
\hline Financial Records & $\mathrm{n}=63$ \\
No any records reported & $07(11.1)$ \\
Diary/book & $51(81.0)$ \\
Book keeping & $04(6.3)$ \\
Using Computers & $01(1.6)$ \\
Using standardized system & $0(0.0)$ \\
Age of Business & \\
$1-5$ & $27(42.8)$ \\
$6-9$ & $33(52.4)$ \\
$10-14$ & $02(3.2)$ \\
$15-19$ & $01(1.6)$ \\
$<20$ & $00(0.0)$ \\
Number of employees & \\
$5-14$ & $41(65.0)$ \\
$15-24$ & $18(28.6)$ \\
$25-34$ & $04(6.4)$ \\
\hline
\end{tabular}

(Source: Survey data, 2019)

Table 07 displays the profile of the firm of SMEs. The diaries and or books are the main financial recording method (81.0\%); most firms are age between 6-9 years, which reveals that 33(52.4\%) and the least percentage indicate $1.6 \%$ for the firms in business age between $15-19$ years; the majority, $65.0 \%$ of employees in between 5 14 numbers.

\subsection{Sources of Financing}

Table 08 sources of financing for operations of SME

\begin{tabular}{ll}
\hline Sources of Financing used by SME & $(\%)$ \\
\hline Personal savings of business owner(s) & 7.4 \\
Bank loan (commercial or personal loans) & 52.2 \\
Loans from other financial institutions & 2.1 \\
Trade credit owning to suppliers & 4.3 \\
Leasing or hire purchase & 5.3 \\
Loan from relatives or friends of business owner(s) & 9.6 \\
Micro-Credit & 19.1 \\
\hline
\end{tabular}

(Source: survey data 2019)

The survey shows that banks' commercial or personal loans are an essential source of SME financing even though the SME has many difficulties dealing with state and private banks. The seeds of funding used by SMEs are present in table 8 . The 52 percent of SMEs reported that they had utilized bank loans (commercial or personal loans) and micro-credit was the second significant financing $(19.1 \%)$.

The other most crucial financing sources include loans from individuals unrelated to the firm. According to the findings, more than 09 percent of SMEs had used each of these sources. Loans from individuals related to an unrelated to the firm highlighted that internal informal financing sources are a popular and vital source that SMEs cannot afford to ignore in Sri Lanka. Leasing financing, trade-credit, and loans from other financial institutions are less critical than the other financial references.

Sri Lankan SMEs are still preferred to use traditional financing sources. When financial institutions that fail to secure formal loans, they would replace these with informal finance. Innovative financial sources like direct financing sources, venture capital, online financing, leasing, and factoring should be encouraged to use. SME financing in Sri Lanka is considered to be expanded rather than commercial bankers. Commercial banks are not adequate to fulfill fundamental requirements. Therefore, direct financing and non-collateral debt should be encouraged for SMEs in Sri Lanka. The stock market should be expanded for SMEs to increase access to equity financing. The number of SMEs listed in the stock market should need to increase.

Uses of innovative financial sources are uncommon according to this sample of the study. Factoring and leasing are the SMEs can get a financial advantage without providing collaterals. Collaterals are a big problem among SMEs. Therefore, using alternative financing sources which aim to minimize such a problem. Noncollateral debt products like financial leasing and factoring should be encouraged in Sri Lanka. The lack of adequate physical collateral to proffer as security for loans is one of the single most considerable SMEs' constraints when seeking access to finance. Online financing is also another innovative instrument for SMEs' financing. It has 
cheaper and high efficiency. More comprehensive regulations and stricter risk-control systems are essential for the growth of SME financing. For example, online finance methods are quickly becoming popular in China, and possibly reshaping the SME financing environment (OECD, 2015).

\subsection{Reasons for obtaining finance}

Table 9 depicts the reasons for getting finance by SMEs in Sri Lanka. The most common sense was fulfilled with capital equipment or vehicle (38\%) and the fulfillment of SMEs' working capital $(33.3 \%)$.

Table 9 Main reasons for obtaining finance

\begin{tabular}{ll}
\hline Reasons & Percentage (\%) \\
\hline Working Capital & 33.3 \\
Capital equipment or vehicle & 38.0 \\
Buying land or building & 17.5 \\
Improving building & 6.3 \\
Other & 4.9 \\
\hline
\end{tabular}

(Source: Survey data 2019)

Constraints to financing SMEs

Table 10 Main constraints

\begin{tabular}{ll} 
Problem & Percentage \\
\hline High interest rate & 02.6 \\
Lack of financial performance records of business & 24.1 \\
Lack of confidence by finance providers about business & 23.3 \\
Lack of securable assets & 15.5 \\
Lack of knowledge about lending criteria used by providers & 16.4 \\
Complex application procedure & 12.9 \\
Other & 05.2 \\
\hline
\end{tabular}

(Source: Survey data 2019)

Constraints to financing SMEs mainly arise from two aspects, which are demand-side factors and supply-side factors. Demand-side factors come from SMEs owner or firm, and supply-side factors come from financing institutions. Table 10 illustrates how respondents rank the difficulty they encountered when applying to the financing requests. The most common complication $(24.1 \%)$ of respondents was the business's lack of financial performance records. The other most commonly highlighted problems are the lack of confidence by finance providers about business (23.3\%), lack of knowledge about lending criteria used by providers $(16.4 \%)$, and lack of securable assets $(15.5 \%)$.

\section{Conclusion}

This research focused on examining the financial innovation of SMEs in Sri Lanka. According to the research findings, SMEs' financing sources mainly consist of bank loans, financial institutions' loans, trade credit, leasing, personal savings, loans from relatives or friends, and microcredits. However, this research finding reveals that commercial banks' commercial or personal loans are the single and most important SME financing source, even though the SME has many difficulties in dealing with banks. The SMEs are still preferred to use traditional financing sources instead of innovative financial sources. SMEs are not having sufficient financial institutions network and lack of knowledge about innovative financial sources.

The financial markets for SMEs are remaining deprived in Sri Lanka compared to international experiences. The banking sector is the primary finance source for SMEs in Sri Lanka, even if many state and private institutions provide finance for SMEs. The majority of Sri Lanka commercial banks offer ATM facilities, debit cards, credit cards, online banking, telebanking, mobile banking, and SME training and post evaluation of loans for their clients as financial innovation approaches. Nevertheless, the problem was that most SMEs are not aware and creative enough to use innovative techniques for their business. Those SMEs are preferred to use traditional methods instead of innovative designs. Further, insufficient bank networks, lack of IT knowledge were identified as the main problems among SMEs in Sri Lanka.

Therefore, considering international experiences, both SMEs and government should rethink financial innovations. Firstly, it should be further developed the existing national policy for SMEs development. Financial problems can be overcome by establishing a proper credit guarantee scheme for SMEs, promoting financial education for SMEs and financial institutions, establishing particular institutions for SMEs, encouraging direct financing, online financing, and other financial sources similar to factoring and venture capital.

\section{References}

Abadeamed, K. H., Wahab, K. A. (2012). Do experience, education, and business plans influence SMEs start-up bank loan? The case of Libya, Australian Journal of Basic \& Applied Sciences, 6 (12): 234-239. 
Abdulsaleh, A. M., Worthington, A. C. (2013). Small and Medium-Sized Enterprises Financing: A Review of Literature, International Journal of Business \& Management, 8 (14): 36-54.

Abereijo, I.O., Abimbola, O.F. (2007). The Attitude of Small and Medium Industrialists to Venture Capital Financing in Nigeria, Global Journal of Business Research, 1(1): 127-138.

Ahmed, M.N., Chowdhury, M.I. (2007). Non-bank financial institutions in Bangladesh: An analytical review, Policy Analysis Unit, Bangladesh Bank.

Alina, B. (2011). Start-Up Financing Sources: Does Gender Matter? Some Evidence for E.U. and Romania, Annals of the University of Oradea Economic Science, 1 (special): 207-213.

Arena, M. P. (2011). The corporate choice between public debt, bank credit, traditional private debt placements, and 144A debt issues. Review of Quantitative Finance and Accounting, 36 (3): 391-416.

Aryeetey, E. (2002). Informal Finance for Private Sector Development in Africa. African Development Bank Group, 7 (1):1-31.

Beck, T., Demirgüç-Kunt, A., Laeven, L., Maksimovic, V. (2006). The determinants of development barriers, Journal of International Money \& Finance, 25 (6): 932-952.

Beck, T., Demirgüç-Kunt, A., Maksimovic, V. (2008). Financing patterns around the world: Are small meetings different?, Journal of Financial Economics, 89 (3): 467-487.

Beck, T., Demirguc-Kunt, A. (2006). Small and medium-sized enterprises: Access to finance as a growth constraint, Journal of Banking \& Finance, 30 (11): 2931-2943.

Belleflamme, P., Lambert, T., Schwienbacher, A. (2011). Crowdfunding: Tapping the right crowd, Core Discussion Papers, 29 (5): 585-609.

Berger, A.N. \& Udell, G. F. (2006). A more complete conceptual framework for SME finance. Journal of Banking \& Finance, 30 (11): 2945-2966.

Boscoianu, M., Prelipean, G., Calefariu, E., Lupan, M. (2015). Innovative Instruments for SME Financing in Romania - a New Proposal with Interesting Implications on Markets and Institutions, Procedia Economics \& Finance, 32(12):240-255.

Chao, X., Zhou, Z. (2013). The Evolutionary Game Analysis of Credit Behavior of SME in Guaranteed Loans Organization, Procedia Computer Science, 17(3): 930-938.

Cusmano, L. (2015). New approaches to SME and Entrepreneurial Financing: Broadening the Range of Instruments, OECD, France.

Department of Census and Statistics (2015). Non-Agricultural Economic Activities in Sri Lanka- Economic Census, Colombo, Sri Lanka.

Eniola, A.A., Entebang, H. (2015). SME firm performance-financial innovation and challenges, Procedia-Social and Behavioral Sciences, 195:334-42.

Fatoki, O. O., Asah, F. (2011). The Impact of Firm and Entrepreneurial Characteristics on Access to Debt Finance by SMEs in King Williams' Town, South Africa, International Journal of Business \& Management, 6(8): $170-179$

Frame, W.S., White, L. J. (2004). Empirical Study of Financial Innovation: Lots of Talk, Little Action? Journal of Economic Literature, 42 (1): 116-144.

Galindo, A.J., Schiantarelli, F. (2002). Credit Constraints in Latin America: An Overview of the Micro Evidence, SSRN Electronic Journal, 43(5): 537-549.

Gamage, A.S. (2003). Small and medium enterprise development in Sri Lanka: A review. Meijo University, Faculty of Business Management, Nagoya, Japan.

Gbandi, E.C., Amissah G. (2014).Financing options for small and medium firms (SMEs) in Nigeria, European Scientific Journal, 10(1):327-340.

Gunatilake, M. M. (2018). Factors Affecting Growth of Small and Medium Enterprises in Sri Lanka: International Journal of Advanced Research, 5(2), 1805-1814

Haron, H., Said, S.B., Jayaraman, K., Ismail, I. (2013).

Factors Influencing Small Medium Enterprises (SMES) in Obtaining Loan. International Journal of Business and Social Science, 4(1):182-196.

Hossain, M.M. (2013). Leasing: An Alternative Financing Mechanism for SMEs, ABC Journal of Advanced Research, 2(1): 66-82.

Huda, A. N. (2012). The Development of Islamic Financing Scheme for SMEs in a Developing Country: The Indonesian Case. Procedia - Social and Behavioral Sciences, 52(1): 179-186.

Hunjra, A. I. (2011). Determinants of Business Success of Small and Medium Enterprises, Social Science Electronic Publishing, 2 (20): 274-280.

Ibrahim, N., Verliyantina. (2012). The Model of Crowdfunding to Support Small and Micro Businesses in Indonesia Through a Web-based Platform, Procedia Economics \& Finance, 4(3):390-397.

Ionescu, C. (2012). Financial Instability and Financial Innovations, Economy Trans disciplinary Cognition, 15(1): $30-37$. 
Kraemer-Eis, H., Lang, F. (2012). The importance of leasing for SME finance. EIF Research \& Market Analysis, Luxembourg.

Kyaw, A. (2008). Financing Small and Medium Enterprises in Myanmar, Ide Discussion Papers, Institute of Developing Economics, Japan.

Lee, N., Sameen, H., Cowling, M. (2015). Access to finance for innovative SMEs since the financial crisis, Research Policy, 44 (2): 370-380.

Lin, P. (2012). Game Analysis of SME Financing, Journal of Financial Risk Management, 1 (4): 64-67.

Mazzucato, M. (2013). Financing innovation: creative destruction vs. destructive creation. Industrial \& Corporate Change, 22 (4): 851-867.

Megersa, K. (2020). Improving SMEs' Access to Finance through Capital Markets and Innovative Financing Instruments: Some Evidence from Developing Countries, Institute of Development Studies.

Moro, A., Lucas, M., Kodwani D. (2010). Small and medium-sized enterprises (SMEs) and their cost of capital, International Conference on Management of SMEs, 2-14.

Nanayakkara, G. (2011). Enhancing the Capacity of Banks to Shaping Development of SMEs. Association of Professional Bankers in Sri Lanka.

OECD. (2015). Financing SMEs and Entrepreneurs 2016: AN OECD Scoreboard, OECD Publishing.

Olawale, F., Garwe, D. (2010). Obstacles to the growth of new SMEs in South Africa: A principal component analysis approach, African journal of Business Management, 4(5):729.

Osano, H.M., Languitone, H. (2016). Factors influencing access to finance by SMEs in Mozambique: Case of SMEs in Maputo central business district, Journal of Innovation and Entrepreneurship, 5(13). DOI 10.1186/s13731-016-0041-0

Prelipcean, G., Boscoianu, M. (2014). A hybrid framework for SME financing based on the mix between governmental support and the use of a specialized investment fund in the actual context of a slow recovery after crises and turbulences, Procedia Economics and Finance, 31(15):738-45.

Pretorius, M., Shaw, G. (2004). Business Plans in Bank Decision-Making when Financing New Ventures in South Africa, South African Journal of Economic and Management Science, 7(1):221-241.

Prohorovs, A., Beizitere, I. (2015). Trends, Sources and Amounts of Financing for Micro-Enterprises in Latvia, Procedia - Social and Behavioral Sciences, 21(3): 404-410.

Punyasavatsut, C.H. (2011). SMEs access to finance in Thailand. Small and Medium Enterprises (SMEs) Access to Finance in Selected East Asian Economies, ERIA, Indonesia: 193-230.

Quaye, I.S., Sarbah, A.L. (2014). Assessing Alternative Sources of Financing for Small and Medium Scale Enterprises in Ghana Case Study of Savings and Loans Companies (S\&Ls) in the Greater Accra Region in Ghana, International Journal of Advancements in Research \& Technology, 3(1):123-36.

Rakićević, Z., Omerbegović-Bijelović, J., Lečić-Cvetković, D. (2016). A model for effective planning of SME support services, Evaluation \& Program Planning, 54:30-40.

Rupeika-Apoga, R., Danovi, A. (2015). Availability of Alternative Financial Resources for SMEs as a Critical Part of the Entrepreneurial Eco-System: Latvia and Italy, Procedia Economics \& Finance, 33(1):200-210.

Rupeika-Apoga, R. (2014). Access to Finance: Baltic Financial Markets, Procedia Economics \& Finance, 9 (4): 181-192.

Salikin, N., Wahab, N.A., Muhammad, I. (2014). Strengths and Weaknesses among Malaysian SMEs: Financial Management Perspectives, Procedia - Social and Behavioral Sciences, 129(1): 334-340.

Schiffer, M., Weder, B. (2001). Firm Size and the Business Environment, PLOS ONE, 2001, 8 (12): 82904-82912.

Shen, Y., Shen, M., Zhong, X.U., Bai, Y.I. (2009). Bank Size and Small- and Medium-sized Enterprise (SME) Lending: Evidence from China, World Development, 37 (37): 800-811.

Song, M., Ai, H., Li, X. (2015). Political connections, financing constraints, and the optimization of innovation efficiency among China's private enterprises, Technological Forecasting \& Social Change, 92 (3): 290-299

Tchankam, J. P., Feudjo, J. R., Gandja, S. V. (2016). The determinants of financial structure: How to explain the "paradox of insolvency and debt" among SMEs in Cameroon?, Research in International Business \& Finance, $36(2): 73-84$

Thanh, V., Cuong, T.T., Dung, B.U., Chieu, T.D. (2011). Small and Medium Enterprises Access to Finance in Vietnam. Small and Medium Enterprises (SMEs) Access to Finance in Selected East Asian Economies, ERIA Research Project Report, Jakarta, 151-92.

Tsai, K. S. (2015). Financing Small and Medium Enterprises in China: Recent Trends and Prospects beyond Shadow Banking, Social Science Electronic Publishing, New York, USA.

Tufano, P. (2003). Financial Innovation. Handbook of the Economics of Finance, 1 (03): 307-335.

Wickremasinghe, S.I. (2011). Status of SMEs in Sri Lanka, Tech Monitor, New Delhi, India, 11-19.

Widuto, A. (2014). Crowdfunding - an alternative financing option for SMEs, European Parliamentary Research Service Blog, Brussels, Belgium.

Wilson, N., Summers, B. (2002). Trade Credit Terms Offered by Small Firms: Survey Evidence and Empirical 
Analysis, Journal of Business Finance \& Accounting, 29 (3-4): 317-351.

Zeneli, F., Zaho, L. (2014). Financing SMEs in Vlora City, Albania: between Game Theory and Lack of Information, Procedia - Social and Behavioral Sciences, 150(1): 126-131. 